DOI https://doi.org/10.30525/978-9934-26-038-4-58

\title{
ВИКОРИСТАННЯ ПРОСТАТИЛЕНУ ПРИ ЕКСПЕРИМЕНТАЛЬНОМУ ПРОСТАТИТІ У ДОРОСЛИХ ЩУРІВ
}

\author{
Мараховський I. O. \\ acniрант \\ Державна установа «Інститут проблем ендокринної патології \\ імені В. Я. Данилевського \\ Національної академії медичних наук Украӥни» \\ Белкіна I. O. \\ кандидат біологічних наук, \\ в.о. наукового співробітника лабораторії \\ репродуктивної ендокринології \\ Державна установа «Інститут проблем ендокринної патології імені \\ В. Я. Данилевського Національної академї медичних наук Украӥни»
}

\author{
Величко Н. Ф. \\ кандидат біологічних наук, \\ в.о. наукового співробітника лабораторії \\ репродуктивної ендокринології
}

Державна установа «Інститут проблем ендокринної патологї

імені В. Я. Данилевського

Національної академії медичних наук Украӥни»

\section{Смолснко Н. П.}

кандидат біологічних наук,

стариий науковий співробітник лабораторії

репродуктивної ендокринології

Держсавна установа «Інститут проблем ендокринної патології

імені В. Я. Данилевського

Національної академії медичних наук України»

\section{Бондаренко В. О.}

доктор медичних наук, професор,

в. о. завідувача лабораторії репродуктивної ендокринології

Державна установа «Інститут проблем ендокринної патологї імені В. Я. Данилевського

Національної академії медичних наук України» м. Харків, Украӥна

Простатит є найпоширенішим запальним захворюванням чоловічої статевої сфери. Для нього характерний тривалий, рецидивуючий 
перебіг, що призводить до зниження фертильності, а в 40-50\% випадків - до безпліддя [1]. На хронічний простатит хворіють переважно чоловіки репродуктивного віку, що суттєво знижує якість їхнього життя, оскільки негативно впливає на взаємовідносини, працездатність [2]. Тому своєчасне виявлення та лікування простатиту наряду з медичним має величезне соціальне значення.

Для лікування простатиту часто застосовують простатичні пептиди, що екстрагують із передміхурової залози великої рогатої худоби [3]. До таких препаратів належить Простатилен, який чинить простатопротекторну дію, завдяки протизапальному, міотропному ефектам, покращенню процесів мікроциркуляції [4], в той же час вплив цього препарату стосовно гістоморфоструктури передміхурової залози, андрогенного статусу, процесу сперматогенезу потребує додаткових досліджень.

Мета: визначення впливу Простатилену на морфологічний стан передміхурової залози, рівень тестостерону, стабільних метаболітів циклу азоту та параметри спермограми дорослих щурів із простатитом.

Матеріали та методи. Дослідження проводилися на самцях щурів популяції Вістар відповідно до національних «Загальних етичних принципів експериментів на тваринах», згідно 3 положеннями Свропейської конвенції. У роботі були використані статевозрілі самці щурів, у яких було змодельовано простатит шляхом кріотравмування вентральної частини передміхурової залози за допомогою кріопристрою Wartner (виробник Omega Pharma International, Бельгія). Контрольну групу складали хибнооперовані тварини.

3 метою корекції експериментального простатиту починаючи з 15 доби після операції щурам протягом двох тижнів вводили $0,5 \%$ гель Простатилену per rectum в об'ємі 0,5 мл в верхній відділ прямої кишки на глибину 20-25 мм. Тварин виводили з експерименту шляхом швидкої декапітації. Дослідження стану сперматогенезу проводили, визначаючи концентрацію епідидимальних сперміїв, їх рухливість і відсоток патологічних форм, окрім того вимірювали рівень загального тестостерону та стабільних метаболітів циклу азоту в сироватці крові, вивчали морфологічну картину передміхурової залози шляхом перегляду мікропрепаратів вентральної частини залози під світловим мікроскопом Granum. Статистичну оцінку проводили 3 використанням критерію Q Дана. Відмінності вважали статистично значущими при $\mathrm{p}<0,05$.

Результати досліджень. Кріотравмування вентральної частини передміхурової залози викликало ознаки запалення у паренхімі залозистої тканини, які характеризувалися розтягненням кінцевих відділів більшості простатичних залозок, атрофією залозистого епітелію, згущенням і застоєм секрету, продуктивною запальною реакцією, огрубінням строми. Розвиток кріотравматичного простатиту супроводжувався зниженням на $35 \%$ загального тестостерону, збільшенням у 1,7 раза вмісту стабільних метаболітів циклу азоту в сироватці крові та погір- 
шенням всіх показників спермограми, а саме: зниженням загальної концентрації сперматозоїдів (на 40 \%), концентрації морфологічно нормальних сперматозоїдів (на $45 \%$ ), зниженням рухливісті сперміїв (на 44 \%) та збільшенням частки аномальних форм клітин (у 2,8 рази).

Ректальне введення Простатилену тваринам із простатитом зменшувало прояви атрофічних, деструктивних і склеротичних процесів у передміхуровій залози, розвиток запалення тканини та огрубіння строми. Позитивний вплив позначався і на андрогенсинтетичній та сперматогенній функції сім'яників. Вміст загального тестостерону у сироватці крові наближався до контрольних значень інтактних тварин: $(19,0 \pm 0,3)$ нмоль/л проти $(20,3 \pm 0,9)$ нмоль/л відповідно. Нормалізувались показники спермограми: у порівнянні з групою тварин із експериментальним простатитом спостерігалось збільшення загальної концентрації сперматозоїдів на $43 \%$ та на 53 \% збільшення концентрації морфологічно нормальних клітин, збільшення кількості рухливих сперматозоїдів на $36 \%$ та зменшення на $50 \%$ частки патологічних форм гамет.

Спостерігалося також покращення антиоксидантного захисту: вміст стабільних метаболітів циклу азоту в сироватці крові піддослідних самців після застосування Простатилену відповідав показникам інтактних тварин: $(5,22 \pm 0,18)$ мкмоль/л проти $(5,08 \pm 0,31)$ мкмоль/л у контролі.

Висновки. 1. Кріотравмування вентральної частини передміхурової залози призводить до виникнення простатиту, що характеризується морфологічними змінами у паренхімі залозистої тканини, розвитком запальної реакції у простаті, що позначається порушенням процесів вільно-радикального окислення, пригніченням андрогенсинтетичної та сперматогенної функції сім'яників. 2. Застосування Простатилену у щурів із експериментальним простатитом нормалізує сперматогенез, рівень тестостерону, стабільних метаболітів циклу азоту, сприяє зниженню запальної реакції, зменшує прояви деструктивних процесів передміхурової залози, що свідчить про його простатопротекторну дію.

\section{Література:}

1. Яковец Я. В. Хронический абактериальный простатит и патоспермия: механизмы взаимосвязи и возможности иммуномодулирующей коррекции Эффективная фармакотерапия. 2019. Т. 15. №. 10. C. 30-33.

2. Необходимость комплексного подхода к обследованию и лечению больных хроническим абактериальным простатитом / Е. В. Кульчавеня и др. Экспериментальная и клиническая урология. 2017. № 3. С. $84-89$.

3. Простатический биорегуляторный полипептид простатилен: фармакологические свойства и опыт 30-летнего клинического применения в урологии / И. В. Кузьмин и др. Урологические ведомости. 2020. T. 10. №. 3. C. 243-258. 
4. Влияние препарата Простатилен® АЦ на фрагментацию ДНК сперматозоидов при лечении пациентов с хроническим абактериальным простатитом и сопутствующими нарушениями репродуктивной функции / С. Ю. Боровец и др. // Андрология и генитальная хирургия. 2017. № 3. C. 54-58.

DOI https://doi.org/10.30525/978-9934-26-038-4-59

\title{
МІКРОБІОЛОГІЧНИЙ СКРИНІНГ ВЛАСТИВОСТЕЙ МАТЕРІАЛІВ НА ОСНОВІ БІОПОЛІМЕРІВ ТА АНТИСЕПТИКІВ
}

\author{
Назарчук О. А. \\ доктор медичних наук, \\ дочент кафедри мікробіологіі
}

Вінницький національний медичний університет імені М. І. Пирогова м. Вінниця, Украӥна

Грузевський О. А. кандидат медичних наук, дочент кафедри мікробіології, вірусологї̈ та імунології Одеський національний медичний університет м. Одеса, Украӥна

Дениско Т. В. асистент кафедри мікробіології, вірусології та імунології, Одеський національний медичний університет м. Одеса, Украӥна

Чорнопищук Р. М. кандидат медичних наук, асистент кафедри загальної хірургіі

Вінницький національний медичний університет імені М. I. Пирогова м. Вінниця, Украӥна

Кагляк М. Д. асистент кафедри мікробіології, вірусології та імунології Одеський національний медичний університет м. Одеса, Украӥна

Актуальність. Інфекції, пов'язані $з$ наданням медичної допомоги (ІПМД), спричиняють мікроорганізми, які володіють стійкістю до 